\title{
The Politics of Reparations: The Academic Epistemic Communities and the Implications of Reparation Debate on African-American and Africa's Quest for Reparations
}

\author{
Emmanuel E. Obuah \\ Department of History \& Diplomatic Studies, University of Port Harcourt, Port Harcourt, Nigeria \\ Email: omuse1999@gmail.com
}

Received 1 July 2015; accepted 4 January 2016; published 7 January 2016

Copyright (C) 2016 by author and Scientific Research Publishing Inc.

This work is licensed under the Creative Commons Attribution International License (CC BY). http://creativecommons.org/licenses/by/4.0/

\begin{abstract}
The discourse on reparation for African Americans has gained impulse and will continue to gain significance in the future. The reparation scholarship reached new levels since the 1980 s due to the impetus from the legislative precedent set by the US Congress in passing the Civil Liberties Act of 1988 which provided the basis for compensation to Japanese Americans interned during the Second World War. As for reparations for Africa and other nations that suffered under the transatlantic slave trade and the European colonialism, there is an absence of political will to articulate demands for reparations for and present them at international forums. This paper examines the existing scholarship on reparation for African America. To understand the key arguments, the paper identified three main broad academic epistemic communities and other subdivisions on reparations for African Americans and Africa. It is hoped that this paper will provide some insights to policy makers and scholars.
\end{abstract}

\section{Keywords}

Reparations, Epistemic Communities, Tort Model, Atonement

\section{Introduction}

Reparation may denote any of the following: payment of debt owed; an act of repairing a wrong or injury; to atone for wrongdoing; to make amends; to make one whole again the payment of damages; to repair a nation, compensation in money, land, or materials for damages. Writing on reparations for African-Americans, Brooks 
(2004: p. IX) defined reparation as "a moral obligation to apologize and to make that apology believable by doing something tangible”. For African-Americans, Ogletree Jr. (2002) pointed out that reparation stemmed from, but not limited to a "breach of contract" between the newly freed slaves and the government after the Emancipation Proclamation in 1863, and the subsequent promise under the promise of "a plot of not more than (40) forty acres of tillable ground" issued by General William T. Sherman.

The discourse on reparation for African-Americans has gained momentum and will continue to gain significance in the future. The reparation scholarship reached new levels since the 1980s due to the impetus from the legislative precedent set by the US Congress in passing the Civil Liberties Act of 1988 which provided the basis for compensation to Japanese Americans interned during the Second World War. This created the notion that African-Americans' quest for reparation was a derivative of the above case. On the contrary, historically, it is more germane to say that African-Americans' demand for reparation predates both the Jewish Holocaust and Japanese American settlements. There is no doubt that what began as individual efforts (such as those by Paul Cuffe, Gustavas Vassa, Benjamin Banneker, Phillis Wheatley, Bishop Henry M. Turner and Jupiter Hammon for whom reparation meant a return to Africa), later crystallized in constructive demand for compensatory and restorative justice which characterized the end of the Civil War to the 1930s. More significantly it became a product of the Civil Rights Movement of the 1960s and 1970s. The objective of this paper is to contribute to the ongoing scholarship on reparation discourse by identifying the epistemic communities, examining their core arguments on the issue of reparation to African-American, and their implications to the wider issues of reparations to Africa for slave trade and colonialism.

\section{Historical Background to Reparation}

The idea of reparation to African-Americans has a long and chequered historiography beginning from black leaders like Frederick Douglass, Martin Luther King Jr., to international and Pan African organizations such as the Marcus Garvey's Universal Negro Improvement Association (UNIA), the Pan Africanist Movement, and the controversial ideologies of DuBois and Malcom X. Following the activism of reparation, Verdun (1993) identified four stages/phases of the reparation movement, and Brooks (2004) has divided these activisms into three main periods: the slavery, the post-slavery, and the post-Holocaust periods.

Following the demand in 1969 for the payment of $\$ 500$ million to Blacks from the Churches and Synagogues by African-American activist, James Forman; the United States Government reparation payments to various groups (Alaska Natives Land Settlement in 1971, the Klamaths of Oregon in 1980, the Seminoles of Florida in 1985, and the Japanese Americans 1990); the HR. 40 bill of Congressman John Conyer in 1989; the formation of the National Coalition of Black Reparation Activists (N'COBRA); and the publication of Randall Robinson's The Debt: What America owes to Blacks, the post-Holocaust era has witnessed the reemergence and revivalization of the moral and legal arguments in favor and against reparations. Similarly since the 1990s, reparation debate has become a serious issue of focus in college campuses and editorials of leading newspapers. For example, in 2003, the Boston College Law School hosted a symposium on reparation in memory of Arthur C. Harris. Prior to this event, the database of Lexis-Nexis indicated that there were 85 stories on slavery and reparations before 1991, 83 stories in 1995, 103 stories in 1999, 396 stories in 2000, and 1117 stories in 2001 (figures cited in Brophy, 2004). As a result, reparation has gained currency and credibility throughout the world as nations discuss how they can repair the past damage and obtain closure even though western nations have been willing to stop real discussions on reparations (Tutu, 2003). For example, on August 2001, a World Conference Against Racism was held in Durban, South Africa. Evidence of this growth and awareness on reparation debate, especially in the case of reparation to African-American descendants was the proliferation of reparation litigations in US courts. For examples, Cato v. United States 1995; Obadele v. United States 2002; Abdullah v. United States 2003; Bell v. United States 2001; Powell v. United States 1994; Jackson v. United States 1994; Lewis v. United States 1994; United States v. Bridges 1999; Wilkins v. Commissioner 2003; Farmer-Paellmann v. Fleet Boston Financial Corp \& Aetna Inc. 2002.

However, in terms of mother Africa's quest for reparation for the Atlantic slave trade, and the injustices and exploitation inflicted on the continent from partition through colonial rule, the scholarship, support and interest have been slow. But the arguments for reparations to Africa are strong based on the fact that the slave trade led to the kidnapping of millions of Africans who were sold as slaves to the New World. Also during the periods of slave trade and colonialism, Africa's economic, social and political life were dislocated and distorted. Further- 
more, in both periods massive wealth from Africa were expropriate for the development of Europe (Rodney, 1974; Amin, 1976; Allen, 1998). Although interest and support for Africa's quest for reparation gathered momentum in the 1990s with the hosting of the first Pan African conference on reparation in Nigeria and the subsequent UN World Conference Against Racism, Racial Discrimination, Xenophobia and Related Intolerance in 2001, it soon dissipated. However, there is a third generation of scholarship which is expanding outside of the United States which is reinvigorating the calls for reparations to expand beyond the context of the slave trade to colonialism and apartheid (Brophy, 2004). This is evidenced in the writings of Malavet, 2002; Spitzer, 2002; Roman, 2002; and the proposal to set June 7-9, 2007 as the dates for the International Tribunal on Reparations for Afrikan People (ITRAP) (The Burning Spear (2006); and the August 1, 2006 Global Pan Afrikan Repatriation and Reparation Conference in Accra, Ghana organized by N'COBRA International Affairs Commission (NIAC).

As support for reparations accentuated, so was the academic debate in favor or against. Within the epistemic communities, there are moral, legal, economic and social arguments to justify reparation, as well as significant body of views against reparation in whatever form, or shape. Even among the proponents of reparation (Lewis 1998; Robinson, 2000; Winbush 2001; Ogletree Jr., 2003a; Brooks, 2004), there are those who favor the tort model (e.g. Robinson, 2000; Ogletree Jr., 2003a), and those who opt for the atonement/redemption model (for examples, Brooks, 2004; and Miller 2004). The result is that there is a thriving diversity of views on reparation leading to confusion and misunderstanding of the substance of the scholarship. While the opponents of reparation acknowledge that African Americans have been systematically disadvantaged as a result of slavery and its aftermath, they argue that reparation presents a plethora of technical problems (Reed Jr., 2000). For examples, the distinction between what Bittker (1969) called "recent" wrongs of Jim Crow, and the "ancient" ones of slavery, or the issue of the prohibitive cost of reparation, or the problems of determining who would represent African Americans and the legitimacy of such group. At the political level, while politicians were aware of the sensitivity of the issue and have recognized the inhumane treatment to slaves, others have called for outright apology to Africa and African Americans. For instance, while both President Clinton and Prime Minister Tony Blair expressed deep remorse and deep sorrow over slavery, some African-American members of the Virginia legislature asked the state government to apologize for its role in slavery.

There are also serious recognition of atrocities of slavery and the ill-treatment of the victims by some state legislatures in the United States. Accordingly, some states and municipalities have passed at least four statutes addressing reparations for Africa-Americans, most notably in Rosewood, Florida 1994, Chicago 2002, California 2003, and Oklahoma 2003 (Ogletree Jr., 2003a). But regrettably, Rep. John Conyer's repeated bill H.R.40 demanding the US Congress to investigate the issue of slavery and recommend appropriate reparation has failed. These views are synthesized and presented below.

\section{Epistemic Academic Communities on Reparation}

Reparation to African Americans is a highly controversial and divisive issue not only between black and white but among African Americans. It is controversial because it seeks more than a mere acknowledgement of the centuries of deprivations suffered by African Americans at the hands of the state and federal governments, corporations and individuals during decades of slavery and Jim Crow. In broad terms, there are two epistemic communities, namely those opposed to reparation, and those in favor of reparations. Within the epistemic community favorable to reparations, there are first, those who favor the use of tort model hence referred to as activism and confrontationalism in their approach, and second, those who support reparation not from the narrow legalisms and monetary compensation which characterize most conventional debate but more significantly on how America can redeem its racial injuries by focusing the debate on atonement. And the third group consists of those who recognize the need for apology but are very skeptical and have no faith if the African Americans would ever be compensated for injuries incurred during slavery and Jim Crow period because of the herculean legal obstacles (Dawson \& Popoff, 2004).

\subsection{The Opposition Epistemic Community}

This epistemic community consists of those who are not only critical but are seriously opposed to any form of reparation to African Americans due to past injuries and injustices from the institution of slavery and the Jim Crow era. The anti-reparationists while recognizing the connection between slavery and racism contend that the 
nexus between slavery and the present forces that produce the sense of injustices felt by African Americans today is too attenuated to merit a judicial award of damages on restitution (Massey, 2004). Prominent anti-reparationists, especially the way the debate has been constructed by activist/confrontionist reparations include D’Souza (1995), Horowitz (2001, 2000), Reed Jr. (2000); McWhorter (2001, 2003). Anti-reparation writings gained momentum following the publication of the notorious anti-reparation advertisement by Horowitz (2001) in several university campus newspapers (and have since appeared on several Internet sites). Horowitz (2001) proposed ten reasons why the idea of reparation for blacks was factually tendentious, morally incoherent and racially incendiary. These were that: "there is no single group clearly responsible for the crime of Slavery; there is no one group that benefited exclusively from its fruits; only a tiny minority of white Americans ever owned slaves, and others gave their lives to free them; America today is a multi-ethnic nation and most Americans have no connection (direct or indirect) to slavery; the historical precedents used to justify the reparations claim do not apply, and the claim itself is based on race not injury; the reparations argument is based on the unfounded claim that all African-American descendants; the reparations claim is one more attempt to turn African Americans into victims. it sends a damaging message to the African-American community; reparations to African Americans have already been paid; what about the debt blacks owe to America?; and the reparations claim is a separatist idea that sets African Americans against the nation that gave them freedom. Before Horowitz's publication, D’Souza (1995) had argued that Americans today probably owed nothing to African Americans, and if there was any social debt, it was to the slaves who have died.

Others (Reed Jr., 2000; Jacoby, 2000, 2001) oppose reparation for slavery as dreadful, unjust, and illogical and questionable means in which African Americans mobilized around earlier generations' grievances to pursue current objectives. Yet others (McWhorter, 2001, 2003) while opposing reparation as presently constructed by tort epistemic community describe reparation as "Blood Money" and argued that the plans and programs of reparations have already been implemented and made accessible to African Americans through the services of Community Corporations, Community Reinvestment Act, Affirmative Action policies etc. Yet others like Shipp (2003) pointed out that African Americans should in fact concede that they were indeed Americans and that America has, in numerous ways admitted its past injustices: from the abolitionist movements of the eighteenth and nineteenth centuries, to the 1960's President Johnson's Great Society program, and the subsequent apologies for slavery by presidents Clinton and George W. Bush. In general, most of the anti-reparationist arguments centered on the following: that reparation is unfair since it sought today's White Americans who did not have slaves to pay for restitution for slavery; that reparation would create racial and ethnic strife by resurrecting painful memories that Americans would rather forget; that those who would collect reparations were never slaves or even the children or grandchildren of slaves; that there was no single group that was clearly responsible for the crimes of slavery and no one group that benefited exclusively from it; and that historical precedents used to justify the claim for reparations do not apply. For an articulation of these views against reparation see Horowitz (2001), Jacoby (2001), Sowell (2000), Reed Jr. (2000), Swain, (2002).

\subsection{The Proponent Epistemic Community}

This epistemic community is generally in favor of reparation payment to African-Americans for the harm and injustices inflicted on slaves during slavery, the breach of the contract after the emancipation of slaves, and the injustices against African-Americans during the Jim Crow period. Generally, this community believes that there are connections between the injuries, deprivations, and injustices suffered by slaves and the generations of descendants of slaves. They therefore want the world to understand the impact of slavery on Africa and on African Diaspora, and for those countries and governments responsible for these obnoxious activities to pay reparations. Leading proponents of the reparation epistemic community such as America (1993, 1996, 1999), Munford (1996), Robinson (2000), Ogletree Jr. (2002, 2003a, b, 2004), Winbush (2003), and Robinson (2004) while recognizing that African-Americans were not the only groups to suffer in America, point out that African-Americans' case was different. Slavery was a legalized institution sanctioned and enforced by law and was followed by an era of legalized discrimination and continuing practices that perpetuated black subordination. Proponents of the reparation debate further point out that too many westerners do not appreciate the gravity of removing tens of millions of African people from the African continent, the pain and suffering of the Middle passage odyssey, and the enduring legacy of racism bequeathed by slavery to African Americans and Africans (Ogletree Jr., 2003b). The purveyors of pro-reparation epistemic community admonish those anti-reparationists who say 
that black people should get over slavery and point out that the blacks cannot get over the vicissitudes of slavery because of the lingering effects of the broken promise of equal treatment and the refusal to deal with the baneful record of discrimination (Ogletree Jr., 2003b). Supporters of reparation among other things point out that reparation is justified on the following grounds:

- it is a pay back of accumulated wealth from the labor of emancipated slaves and the failed land redistribution under the Sherman Special Field Orders of 1865;

- it could serve as a symbolic healing that could validate the feelings of the African America community. This could be done through monetary compensation and/or apology by the United States Government which legalized and justified the institution of slavery;

- there exist precedents of United States Government paying reparations to other groups: the Civil Liberties Act (1988) in which the US apologized and paid reparations to interned Japanese survivors from World War II, the payment of compensation for land to various Indian communities, and the payment of reparations to Jews by the German government etc.

However, there are major divisions in this community based on the modus operandi of reparation, the inherent legal hurdles, the scope of the monetary compensation, and the eligibility question. As a result of these divisions, two models have been identified: (a) the confrontational/Demand model or tort model, and (b) the conversation$\mathrm{al} /$ moral argument model or the atonement model (Brooks, 2004; Miller 2004). The central planks of these two models are discussed below.

\subsubsection{The Confrontational/Tort Model}

The confrontational model is primarily characterized by demand for monetary payment from white to blacks for injuries, labor exploitation and discrimination suffered by blacks during slavery and Jim Crow era. This model is represented by writings and views held by Verdun (1993), Robinson (2000), Gilford (1993, 2000), Munford (1996), Ogletree 2001, and organizations such as the Republic of New Africa and N'COBRA, and by such grandiose march like the Million for Reparation march of August 8, 2002. This model not only made a case for monetary compensation to African-Americans, but more significant, to Africa for enslavement of Africans during the trans-Atlantic slave trade and the massive exploitation of the African continent by European nations during the colonial period. Using previous cases of reparation compensation by Germany to the Jews, the US government to Japanese, the Canadian government to Japanese, redistribution of wealth to American Indian tribes by the US government, and payment to Jews by both Hungarian and Slovakian governments in 1994, proponents of this school demand reparation for African Americans for the unpaid and long over due debts, wrongful death and inexhaustible list of deprivation suffered during slavery and Jim Crow period. Within the tort/confrontational model, Massey (2004) identified two models, namely the social welfare model in which reparation is seen as a means of substantial redistribution of wealth (Munford, 1996), and the conventional justice model in which reparation is seen as a means of restoring justice to individuals whose descendants had suffered several deprivations. In fact, Munford (1996: pp. 438-439) proposed that African Americans "should demand it all"- collecting everything owed to us as a people historically, down to the last penny and not one whit less". For him, reparation as a means of redistribution would at a macro-economic level reverse the recession trend that plagued the world economy in the 1980s, and would help jump start the post-Cold War world economy by redistributing excess capacity to the needy Diaspora Blacks and Native Americans and Africa. Therefore, legal approaches ranging from individual law suits to collective class action suit are preferred modus operandi. Some who proffer the social welfare argument have even called for fixed sums of money to compensate AfricanAmericans. This view is supported by the call by James Forman, the leader of Student Non-violent Coordinating Committee (SNCC) in 1969 for $\$ 500$ million reparation from White churches and Jewish synagogues; the call by Republic of New Africa (RNA) in 1972 for \$300 billion in reparation from the US government (Allen, 1998); Reverend Al Sharpton and his Black Agenda's call for \$6.6 billion per year, over ten years; The African National Reparations Organization claim for a figure of \$4.1 trillion for unpaid labor; Reverend Jesse Jackson’s call for reparation in the form of the huge Marshall aid program in the form of the US aid to post-1945 Europe; the N'COBRA's "Black tax" program which was a dollar value put on tax rebate to the Inland Revenue Service (IRS); and the call for between $\$ 96.3$ billion and $\$ 9.7$ trillion for reimbursement of arrears based on the 1983 value for wages between 1620 and 1865 as reparation to African Americans (Neal, 1990 cited in Munford, 1996).

There are a number of fundamental legal obstacles with tort model. They include: 
- sovereignty and immunity question which states and the federal governments have in the US. Private action law suits for example may not generally force the problem of subject-matter jurisdiction arising from defense of sovereign immunity; they may be time-barred by applicable statutes of limitation (Brooks, 2004);

- statute of limitation: issues such as false imprisonment, assault, battery, kidnapping, crimes of slavery etc. have statute of limitation attached to them that leaves only six year window in which to file claims by survivors. This technically excludes reparation case. There must therefore be reasonable arguments to change the statute of limitation as California did, in the case of the Holocaust related lawsuits. Or take the claims to international court where it is recognized that those who commit crimes against humanity must make reparation. But only states can take such case to international court;

- difficulties of identifying victims and of finding out and tracking the perpetrators and the actual transfer and inheritance of wealth among slave holding families;

- difficulties of establishing direct causation, and measurement of harm and the amount of compensation (Yamamoto, 1988; Brophy, 2004).

Proponents of the tort model while recognizing these legal problems, argued that they constituted challenges are not insurmountable. They point to other cases where claims have been made to descendants and by a nation-state which was not in existence when the crime was committed. They also point out that there are identifiable victims or direct descendants of the victims in the case of slavery and the Jim Crow period. As a result, proponents of this model support and have supported a series of private and class action reparation law suits in the United States. Critics of the tort model point out that apart from the aforementioned legal and technical problems, the model cannot make reparation believable for the following reasons:

- litigation inherent in tort model cannot bring forth the sine qua non of redress i.e. a genuine apology for slavery from the main perpetrators - the Federal Government of the United States.

- tort model is inherently adversarial hence antithetical to racial harmony and reconciliation which are the raison d'être for slave redress. Tort main objective is compensation which undercuts the moral basis for redress hence dishonors the memory of the slaves.

- tort model is morally deficient in that it clouds the black redress movement's identity with international human rights movement, rather than seek atonement from the perpetrators as a primary goal (Brooks, 2004).

\subsubsection{The Atonement/Conversational (Moral) Model}

According to Miller (2004) the conversational model is a way of re-characterizing acts or situations in ways that are morally or politically significant. It is a model which at a minimum makes it impossible for citizens to ignore the contributions of slavery and de jure segregation to the character of the American society. It involves ruling out certain notions of desert and failure, responsibility and innocence from the debate on race, discrimination, and their consequences for the American society. For Miller (2004) the question under the moral model is that of the "community", that is, "how to find a common set of valuations that enable us to evaluate the significance of our acts". For Miller, the debate under the tort model interrogates the content of American unity, especially post-2001. But by far the most ardent proponent of the atonement model is Brooks (2004) who tried persuasively to reframe the reparation debate from the tort-dominant model to a forward-looking model in which the United States Government must make sure the pangs and deaths of slaves have posthumous meaning by making reparation and apology believable by a tangible act of material realty. In trying to demonstrate and establish the connection between slavery and position of blacks in contemporary America, Brooks (2004: pp. 36-87) argued that there were evidence of capital deficiencies (social and human capital) linking past conditions of slavery and Jim Crow period to deficiencies among contemporary African American population. While Brooks did not dismiss reparation, he pointed out that the atonement model embraced the core belief that redress should not be primarily about monetary compensation, but about apology, first and foremost, honor, black pride and dignity, and about commemorating and memorializing the slaves (2004: pp. 142-143). According to the atonement model, reparation was essential to atonement because it made apology believable, i.e. turning rhetoric of apology into meaningful material reality and thus repairing the damage caused by the atrocity of slavery and ensuring that the atrocity is not repeated. Apology, according to Brooks (2004: p. 144) was intended to do four things: confession of the deed, admission that the deed was unjust, repentance, and forgiveness. Proponents of the atonement model further argued that it was not all about apology from the perpetrators. It was also about genuine forgiveness by the victims (whether the victims were alive or not). As Brooks (2004) pointed out, victims' forgiveness is essential to the forward-looking reconciling potential of slave redress. Reparation for the atonement model 
could be in two forms: compensatory and rehabilitative (Brooks, 2004: p. 156). While the former was directed toward the individual victims or victims' families, the latter was directed toward the victims' group(s), designed for the benefit of the group and to nurture the group's self-empowerment and aid in the social and cultural transformation of the nation. The atonement model while not eliminating the courts, prescribes a conversational and legislative approach by the communities involved in which redress/reparation is presented as a means of accounting for responsibilities as citizens to each other and acknowledging the responsibility (Brooks, 2004; Miller, 2004).

\section{Epistemic Community on Africa's Quest for Reparation}

Although there is a genuine case for reparation to Africa for slavery and exploitation and dislocation of its economy and cultures, and those of other colonized countries (Gifford, 1993), interest and support for Africa's quest for reparation gathered momentum in the 1990s with the hosting of the First Pan-African Congress on Reparation in Abuja, Nigeria, the preparatory regional conference in 2001 in Dakar, and the UN World Conference Against Racism, Racial Discrimination, Xenophobia and Related Intolerance in 2001 in Durban, South Africa. In the preparatory regional conference for the World Conference against Racism, Racial Discrimination, Xenophobia and Related Intolerance, the African delegates among other things articulated and affirmed a program of action which was presented at the UN Conference in Durban, South Africa. The program of action among other things affirmed:

- that slave trade, particularly of Africa, was a unique tragedy in the history of humanity, crime against humanity which was unparalleled not only because of its abhorrent barbarism, but also in terms of its enormous magnitude, its institutionalized nature, its transnational dimension, and especially its negation of the essence of the human nature of the victims;

- that the consequences of this tragedy, accentuated by those of colonialism and apartheid, have resulted in substantial and lasting economic, political and cultural damage to the African peoples and are still present in the form of damage caused to the descendants of the victims by the perpetuation of prejudice against Africans in the continent and peoples of African descent in the Diaspora (Winbush, 2003, notes 10 and 11).

The purpose of the Durban conference was to produce a global blue-print for fighting racism and related offences on an international basis. However, at the end, the conference could not pass any consensus resolution due to the United States' concern for the preoccupation of the conference delegates with proposing a resolution that would condemn Israel as a racist country (Brook, 2004). But this interest on reparation to Africa soon dissipated as the United States and the world community became involved in the global war on terrorism in the aftermath of the September 11, 2001 attack on the United States. However, there is a third generation of scholarship which is expanding outside of the United States that is reinvigorating the calls for reparations to expand beyond the context of slavery to colonialism and apartheid. For example, the proceedings of the first Pan-African Conference on Reparations, which was organized by the Organization of African Unity (OAU), 1993; and Mazuri, (2002). The case for the underdevelopment of the African continent by Europe through the barbarity of the slave trade and colonialism has been well documented by Rodney (1974), Amin (1976), and Thomas (1997). Therefore, reparation for the crime against humanity, exploitation, and destruction and dislocation of economic, political and cultural aspects in Africa that accompanied these periods should be made by those who perpetrated the atrocities. As articulated by Gifford (1993) this generation of scholarship is convinced that Africa has a compelling case for reparation for the slave trade and colonialism on the following grounds:

- that the enslavement of Africans was a crime against humanity as defined by the Charter of Nuremberg Tribunal and the International Criminal Court;

- that international law recognizes that those who commit crimes against humanity must make reparation;

- that there is no legal barrier preventing those who still suffer the consequences of crimes against humanity from claiming reparations, even though the crimes were committed against their ancestors;

- that reparation claim can be brought on behalf of all Africans, in Africa and in Diaspora, who suffered the consequences of the crime, via the agency of an appropriate body (State);

- that Africa's claim for reparation could be brought against the governments of those countries which promoted, participated and were enriched by the African slave trade and the institution of slavery;

- that Africa's claim for reparation could be settled by agreement or determined by a special international tribunal recognized by all parties.

In addition to this nascent generation of scholarship, there are emerging organizations in the United States, 
Africa, Europe, Latin America and the Caribbean with transnational focus that are supporting reparation for slave trade, slavery and colonialism. For examples, N'COBRA International Affairs Commission (NIAC) in Ghana, Pan-Afrikan Reparations Coalition in Europe (PARCOE), International Tribunal on Reparations for Afrikan People (ITRAP), the Global Movement for Pan-Afrikan Reparations etc. For these organizations, reparation is encapsulated in statements of Chinweizu (1993), that is:

Reparation is not just about money; it is not even mostly money; in fact, money is not even one per cent of what reparation is about. Reparation is mostly about making repairs, self-made repairs, on ourselves: mental repairs, psychological repairs, cultural repairs, organizational repairs, social repairs, economic repairs, political repairs, educational repairs, repairs of every type that we need in order to recreate and sustain viable Black societies. More important than any monies to be received, more fundamental than any lands to be recovered, is the opportunity the Reparations campaign offers us for the rehabilitation of Black people, by Black people, for Black people, opportunities for the rehabilitation of our minds, our material condition, our collective reputation, our cultures, our memories, our self-respect, our religions, our political traditions and our family institutions; but, first and foremost, for the rehabilitation of our minds.

However, what is lacking in this growing reparation consciousness is the political will by African leadership to articulate demands for reparation and present such demands in various international forums. Like the struggle against colonial rule which formed a platform for coalition among non-aligned countries, reparation could become a platform for African, Latin American and Caribbean countries to form a coalition.

\section{Conclusion}

It has been the task of this paper to contribute to the reparation debate by identifying the various epistemic communities that exist on the subject. The literature on reparation is rich and diverse as well as the academic communities. So far the paper identified and discussed the central planks of the epistemic communities on reparation for African-American, and Africa. The debate has become academic and often dominated by legal luminaries with legal and sometimes technical arguments. The two broad communities have very strong and compelling arguments. There is no doubt that the debate would continue to grow and expand into other issue areas. However, if the debate is to go beyond monetary compensation to redress and atonement more efforts, would be needed to convince and persuade the perpetrators of the significance of reparation and therefore the need for atonement. For Africa and the other nations that suffered during the transatlantic slave trade and European colonialism, it is hoped that reparation would provide a rallying platform to seek redress, atonement and compensation for the atrocities and economic, social and cultural dislocations caused.

\section{References}

Allen, R. (1998). Past Due: The African American Quest for Reparations. Black Scholar, 21, 2-7. http://dx.doi.org/10.1080/00064246.1998.11430911

America, R. (1993) Paying the Social Debt: What White America Owes Black America. Westport: Praeger.

America, R. (1996). Reparations and the Competitive Advantage of Inner Cities. Review of Black Political Economy, 24, 193-206. http://dx.doi.org/10.1007/BF02690030

America, R. (1999). Reparation and Public Policy. Review of Black Political Economy, 26, 77-83. http://dx.doi.org/10.1007/s12114-999-1027-y

Amin, S. (1976). Unequal Development: An Essay on the Social Formations of Peripheral Capitalism. New York: Monthly Review Press.

Brooks, R. (2004). Atonement and Forgiveness: A New Model for BLACK Reparations. Berkeley: University of California Press. http://dx.doi.org/10.1525/california/9780520239418.001.0001

Brophy, A. (2004). Reparations Talk: Reparations for Slavery and the Tort Law Analogy. Boston College 3rd World Law Journal, 24, 81-138.

Chinweizu (1993). Article Name. Address Delivered at the 1st Pan Afrikan Conference on Reparation, Abuja.

D’Souza, D. (1995). The End of Racism. New York: Free Press.

Dawson, M., \& Popoff, R. (2004). Justice and Greed: Black and White Support for Reparation. Du Bois Review: Social Science Research on Race 1(1). Justice and Greed: Black and White Support for Reparation. https://www.researchgate.net/publication/231880343_Reparations_Justice_and_Greed_in_Black_and_White www.ksg.harvard.edu/ineuality/Seminar/Spring03.htm 
Gifford, A. (1993). Reparations: Legal Arguments in Support of Reparations. Paper Presented to the 1st Pan-African Congress on Reparation, Paper Presented to the $1^{\text {st }}$ Pan-African Congress on Reparation, Abuja, Nigeria, 27-29 April 1993. http://www.shaka.mistral.co.uk/legalbasis.htm

Gilford, A. (2000). The Legal Basis of the Claim for Slavery Reparations. Human Rights Magazine, Spring.

Horowitz, D. (2001). Ten Reasons Why Reparations for Blacks Is a Bad Idea for Blacks and Racist Too. http://archive.frontpagemag.com/readArticle.aspx?ARTID=24317

Jacoby, J. (2000). The Case for Reparations to Blacks Is Profound, but It Is Wrong. Boston Globe, 6 March.

Jacoby, J. (2001). The Reparations Calculation. Jewish World Review, 6 February.

Malavet, P. (2002) Reparations Theory and Postcolonial Puerto Rico: Some Preliminary Thoughts. La Raza Law Journal, 13, 387-423.

Massey, C. (2004). Some Thoughts on the Law and Politics of Reparations for Slavery. Boston College Third World Law Journal, 24, 157-176.

Mazuri, A. (2002). Black Reparations in the Era of Globalization. New York: Institute of Global Culture Publications, Binghamton University.

McWhorter, J. (2001). “Blood Money”. The American Enterprise, 12, 18-22.

McWhorter, J. (2003). Against Reparations. In R. A. Winbush (Ed.), Should America Pay? Slavery and the Raging Debate on Reparations (pp. 180-196). New York: Amistad Harper Collins Publishers.

Munford, C. (1996). Race and Reparations: A Black Perspective from the 21st Century. Trenton, NJ: Africa World Press, Inc.

Neal, L. (1990). The Rise of Financial Capitalism. Cambridge: Cambridge University Press.

Ogletree Jr., C. (2002). The Case for Reparations. USA Weekend Magazine. www.usaweekend.com/02_issues/020818/02081reparations.html

Ogletree Jr., C. (2003a). Does America Owe Us? Retrieved from Essence. www.findarticles.com/p/articles/mi_m1264/is_10_33/ai_97117973

Ogletree Jr., C. (2003b). Repairing the Past: New Efforts in the Reparation Debate in America. www.law.harvard.edu/students/orgs/crd/vol38 2/ogletree.pdf

Reed Jr., A. (2000). The Case against Reparations. The Progressive, 64, 15-17.

Robinson, A. (2004). Troubling "Settled” Waters: The Opportunity and Peril of the African-American Reparations. Third World Law Journal, 24, 139-156.

Robinson, R. (2000). The Debt: What America Owes to Blacks. New York: Plume of Penguin Group.

Rodney, W. (1974). How Europe Underdeveloped Africa. Washington DC: Howard University Press.

Roman, E. (2002). Reparations and the Colonial Dilemma: The Insurmountable Hurdles and Yet Transformative Benefits. La Raza Law Journal, 13, 369-382.

Shipp, E. R. (2003). Does America Owe Us? Counterpoint. Retrieved from Essence. www.findarticles.com/p/articles/mi_m1264/is_10_33/ai_97117973

Sowell, T. (2000). Reparations for Slavery? Jewish World Review. http://www.jewishworldreview.com/cols/sowell071700.asp

Spitzer, M. (2002). The African Holocaust: Should Europe Pay Reparations to Africa for Colonialism and Slavery? Vanderbilt Journal of Transnational Law, 35.

Swain, C. M. (2002). The New White Nationalism in America: Its Challenge to Integration. Cambridge: Cambridge University Press.

The Burning Spear (2006). Vol. 25, 3 November.

Thomas, H. (1997). The Slave Trade: The History of the Atlantic Trade 1440-1870. London: PICADOR.

Tutu, N. (2003). Afterword. In R. A. Winbush (Ed.), Should America Pay? Slavery and the Raging Debate on Reparations (pp. 321-325). New York: Amistad Harper Collins Publishers.

Verdun, V. (1993). If the Shoes Fit, Wear It: An Analysis of Reparations to African Americans. Tulsa Law Review, 67.

Winbush, R. A. (Ed.) (2003). Should America Pay? Slavery and the Raging Debate on Reparations. New York: Amistad Harper Collins Publishers.

Yamamoto, E. (1988). Racial Reparations: Japanese American Redress and African American Claims. Boston College Third World Journal Review, 19, 477-523. 